\title{
Root system and resistance to penetration of Mombaça grass fertilized with nitrogen and irrigated ${ }^{1}$
}

\section{Sistema radicular e resistência a penetração de capim Mombaça fertilizado com nitrogênio e irrigado}

\author{
Tatiane Beloni ${ }^{2}$; Vanessa Cristina Piotto ${ }^{3}$; Graciele Caroline Mari \\ Alyson Andrade Pinheiro ${ }^{5}$; Cassio Antonio Tormena ${ }^{6}$; Ulysses Cecato
}

\begin{abstract}
High stocking rates in intensive pasture-based animal production systems may compromise the development of the forage roots due to increased resistance in the surface layer. This study tested the hypothesis that an increase in stocking rate resulting from different levels of nitrogen fertilization in irrigated Mombaça grass (Panicum maximum Jacq. cv. Mombaça) pasture under intermittent grazing could increase resistance to penetration and consequently the growth of the root system. A split-plot design with randomized blocks and subplots was used, including three replications and the following four treatments: 0, 200, 400 and $800 \mathrm{~kg} \mathrm{~N} \mathrm{ha}^{-1}$ year. Evaluations performed in spring, summer and fall seasons were assigned as subplots. The highest values for area, diameter, length and percentage of root biomass $(91.4 \%$ ) were concentrated at the $0-10 \mathrm{~cm}$ soil depth, which is explained by the lower penetration resistance in this layer. Increased stocking rate resulting from increased levels of nitrogen in the Mombaça grass sward does not directly affect the penetration resistance of the soil or root characteristics. However, in the rainy season, higher nitrogen levels lead to increased resistance, as they provide higher cumulative stocking rates in this period.
\end{abstract}

Key words: Irrigation. Nitrogen fertilization. Panicum maximum. Soil compaction.

\section{Resumo}

Elevadas taxas de lotação em sistemas intensivos de produção animal a pasto podem comprometer o desenvolvimento das raízes de forrageiras, devido ao aumento da resistência do solo na camada superficial. Neste estudo testou-se a hipótese que o aumento da lotação animal devido a diferentes doses de nitrogênio em pasto de capim-Mombaça (Panicum maximum Jacq. cv Mombaça), irrigado e sob pastejo intermitente poderiam comprometer a resistência à penetração e consequentemente o crescimento do sistema radicular. Utilizou-se delineamento experimental em blocos ao acaso com parcelas subdivididas, com três repetições e quatro tratamentos: 0, 200, 400 e $800 \mathrm{~kg}^{\mathrm{de} \mathrm{N} \mathrm{ha}} \mathrm{N}^{-1}$ ano. Nas subparcelas foram consideradas as quatro estações do ano. As características geométricas (área,

${ }^{1}$ Parte da dissertação do primeiro autor realizada na Universidade Estadual de Maringá, UEM, financiada pelo CNPq.

2 Pós-Doutoranda, Embrapa Pecuária Sudeste, São Carlos, SP, Brasil. E-mail: tbeloni@usp.br

${ }^{3}$ Discente de Doutorado em Zootecnia, Universidade de São Paulo, USP, Faculdade de Zootecnia e Engenharia de Alimentos, Departamento de Zootecnia, Pirassununga, SP, Brasil. E-mail: vanepiotto@hotmail.com

${ }^{4}$ Discente de Doutorado em Zootecnia, UEM, Departamento de Zootecnia, Maringá, PR, Brasil. E-mail: gracielle_mari@ hotmail.com

5 Pesquisador DCR da EMATER, Agência Goiana de Assistência Técnica, Extensão Rural e Pesquisa Agropecuária, GO, Brasil. E-mail: jagualyson@bol.com.br

${ }^{6}$ Prof. Associado, UEM, Departamento de Agronomia, Maringá, PR, Brasil. E-mail: catormena@uem.br

7 Prof. Titular, UEM, Departamento de Zootecnia, Maringá, PR, Brasil. E-mail: ulyssescecato@gmail.com

* Author for correspondence 
diâmetro e comprimento), e a maior porcentagem de biomassa radicular $(91,4 \%)$ concentraram-se na camada de $0-10 \mathrm{~cm}$ de profundidade, devido a menor resistência à penetração nesta camada. $\mathrm{O}$ aumento da taxa de lotação decorrente do aumento das doses de nitrogênio em pastagem de capim-Mombaça não afeta diretamente a resistência à penetração do solo e as características do sistema radicular. Entretanto, o aumento das doses de nitrogênio no período das águas aumenta a resistência à penetração, proporcionando maiores taxas de lotação acumulada nestes períodos.

Palavras-chave: Adubação nitrogenada. Compactação do solo. Irrigação. Panicum maximum.

\section{Introduction}

Over the last years, the numerous grasses of the genus Panicum (Syn. Megathysus) have become the main options of forage for intensive pasture-based animal production systems (MARTHA JUNIOR et al., 2004). The Mombaça grass stands out for its high dry matter yield potential, quality and palatability of the herbage produced, besides its good persistence (VALENTIM et al., 2001).

However, the choice of techniques that offset the problem of seasonality of forage production must be consistent with the livestock level (SORIA et al., 2003). Nitrogen fertilization generates large increases in forage efficiency and, when associated with irrigation, it can provide reasonable gains in the dry season, in addition to being an instrument to intensify herbage production during the rainy season (LOPES et al., 2003). This implies an increase in the carrying capacity of pastures, more nutritious diets, live weight gain (DIAS et al., 2000) and more kilograms of milk per hectare.

However, an excessive stocking rate can change the physical attributes of the soil surface layer (BERTOLI et al., 2000), which compromises the growth of roots and plants (SARMENTO et al., 2008). Thus, soil resistance to penetration increases (MEROTTO; MUNDSTOCK, 1999), which can undermine the preferential direction of root growth (IIJIMA; KONO, 1991).

The present study tested the hypothesis that increased stocking rates resulting from increasing levels of nitrogen fertilization in Mombaça grass pasture (Panicum maximum Jacq. cv. Mombaça), coupled with irrigation, can increase resistance to penetration and consequently influence the growth of the root system, considering the four seasons of the year, under intermittent grazing.

\section{Material and Methods}

The experiment was carried out on a farm in the city of Santo Inácio, northwestern Paraná State, Brazil. The geographical location is $23^{\circ} 25^{\prime}$ $\mathrm{S}$ and $51^{\circ} 57^{\prime} \mathrm{W}$, at an average altitude of $410 \mathrm{~m}$. The predominant climate in the region is the CFA - humid subtropical mesothermal type (Köppen), characterized by a predominance of warm summers, low frequency of severe frosts, and tendency to rainfall concentration in the summer, with an annual average temperature of $22.1^{\circ} \mathrm{C}$ and annual precipitation of $1200 \mathrm{~mm}$. The evaluation period was from September 2010 to September 2011, comprising the four seasons.

Climatic data of precipitation $(\mathrm{mm})$, relative humidity (\%), and minimum, maximum and mean temperature corresponding to the experimental period can be seen in Figure 1. In early winter (June 24th), there was a severe frost in the region, which greatly affected the pasture.

The soil of the experimental area was classified as dystrophic dark Red Latosol (Rhodic Haplustox) with sandy texture (EMBRAPA, 2009). The soil chemical composition analysis at the beginning of the experimental period (0-20 cm depth) showed the following results: $\mathrm{pH}\left(\mathrm{CaCl}_{2}\right)=5.00 ; \mathrm{P}\left(\mathrm{mg} \mathrm{dm}^{-3}\right)$ $=8.03 ; \mathrm{K}\left(\mathrm{cmol}_{\mathrm{c}} \mathrm{dm}^{-3}\right)=0.10 ; \mathrm{Ca}\left(\mathrm{cmol}_{\mathrm{c}} \mathrm{dm}^{-3}\right)=$ 1.12; $\mathrm{Mg}\left(\mathrm{cmol}_{\mathrm{c}} \mathrm{dm}^{-3}\right)=0.41$; and $\mathrm{H}+\mathrm{Al}\left(\mathrm{cmol}_{\mathrm{c}}\right.$ $\left.\mathrm{dm}^{-3}\right)=2.85$. At the end of the experimental period, the following results were obtained: $\mathrm{pH}\left(\mathrm{CaCl}_{2}\right)=$ 
4.69; P $\left(\mathrm{mg} \mathrm{dm}^{-3}\right)=22.21 ; \mathrm{K}\left(\mathrm{cmol}_{\mathrm{c}} \mathrm{dm}^{-3}\right)=0.13$; $\mathrm{Ca}\left(\mathrm{cmol}_{\mathrm{c}} \mathrm{dm}^{-3}\right)=2.08 ; \mathrm{Mg}\left(\mathrm{cmol}_{\mathrm{c}} \mathrm{dm}^{-3}\right)=0.42$; and $\mathrm{H}+\mathrm{Al}\left(\mathrm{cmol}_{\mathrm{c}} \mathrm{dm}^{-3}\right)=6.26$. The particle size characteristics of the experimental area at 0-10 cm depth were: $10.0\left(\mathrm{~g} \mathrm{dm}^{-3}\right)$ - clay+silt, $7.17(\mathrm{~g}$ $\left.\mathrm{dm}^{-3}\right)$ - clay, $28.46\left(\mathrm{~g} \mathrm{dm}^{-3}\right)$ - fine sand and $9.43(\mathrm{~g}$ $\left.\mathrm{dm}^{-3}\right)$ - grit sand; $10-20 \mathrm{~cm}$ depth: $10.67\left(\mathrm{~g} \mathrm{dm}^{-3}\right)$ clay+silt, $8.0\left(\mathrm{~g} \mathrm{dm}^{-3}\right)$ - clay, $28.91\left(\mathrm{~g} \mathrm{dm}^{-3}\right)$ - fine sand and $8.3\left(\mathrm{~g} \mathrm{dm}^{-3}\right)$ - grit sand; $20-30 \mathrm{~cm}$ depth: $11.83\left(\mathrm{~g} \mathrm{dm}^{-3}\right)$ - clay+silt, $9.0\left(\mathrm{~g} \mathrm{dm}^{-3}\right)$ - clay, 26.11 $\left(\mathrm{g} \mathrm{dm}^{-3}\right)$ - fine sand and $7.39\left(\mathrm{~g} \mathrm{dm}^{-3}\right)$ - grit sand; and 30-40 cm depth: $12.67\left(\mathrm{~g} \mathrm{dm}^{-3}\right)$ - clay+silt, 9.83 $\left(\mathrm{g} \mathrm{dm}^{-3}\right)$ - clay, $26.83\left(\mathrm{~g} \mathrm{dm}^{-3}\right)$ - fine sand and 8.22 $\left(\mathrm{g} \mathrm{dm}^{-3}\right)$ - grit sand.

Figure 1. Precipitation ( $\mathrm{mm}$ ) and minimum, maximum and mean temperature $\left({ }^{\circ} \mathrm{C}\right)$ observed during the experimental period (September 2010 to September 2011).

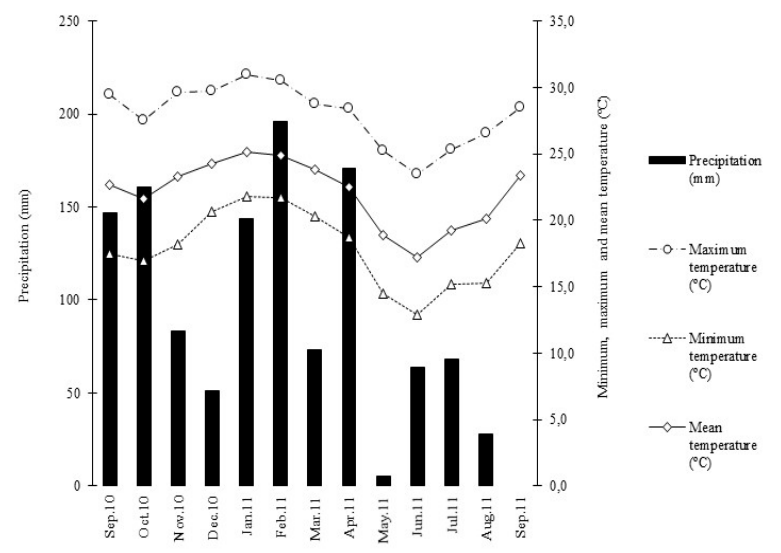

The used area was established in February 2008 with Mombaça grass (P. maximum Jacq cv. Mombaça), with one disking and subsoiling. The total pasture area was approximately 2 ha, and it was divided into three blocks which were subdivided into four paddocks (experimental units), totaling twelve $1,600 \mathrm{~m}^{2}$ paddocks.

A split-plot design with randomized blocks and subdivided plots was used, with three replications and four treatments with Mombaça grass: $0 \mathrm{~kg}$ nitrogen $(\mathrm{N}) \mathrm{ha}^{-1}$ (control); $200 \mathrm{~kg} \mathrm{~N} \mathrm{ha}{ }^{-1} ; 400$ $\mathrm{kg} \mathrm{N} \mathrm{ha}{ }^{-1}$; and $800 \mathrm{~kg} \mathrm{~N} \mathrm{ha}^{-1}$. For the sub-plots, evaluations were carried out in the spring, summer, fall and winter.

For the irrigation of the experimental area, a sprinkler system was installed using the Naan 5035 sprinkler, with $5.0 \times 2.5 \mathrm{~mm}$ nozzles, working pressure of $280 \mathrm{kPa}$, nominal flow rate of $1.875 \mathrm{~L}$ $\mathrm{h}$ and jet inclination angle of $23^{\circ}$, called sprinkler A. One block was irrigated per day, from $21.00 \mathrm{~h}$ to $01.00 \mathrm{~h}$, receiving an average of $7-8 \mathrm{~mm}$, amounting to around $80 \mathrm{~mm}$ per month. This management for distribution of the water was performed according to the storage availability of the reservoir and personnel provided by the farm.

Before the experiment started (June 2010), based on the soil analysis, gypsum and lime (dolomitic limestone) were applied to the soil to raise the base saturation to $70 \%$, following Werner et al. (1996). Phosphate fertilizer was applied once, in September 2010, using simple super phosphate as the phosphorus source $\left(80 \mathrm{~kg} \mathrm{P}_{2} \mathrm{O}_{5} \mathrm{ha}^{-1}\right.$ as ammonium nitrate). Nitrogen $(200,400$ and $800 \mathrm{~kg}$ $\left.\mathrm{ha}^{-1}\right)$ and potassium $\left(120 \mathrm{~kg} \mathrm{~K}_{2} \mathrm{O} \mathrm{ha}^{-1}\right.$ as potassium chloride) fertilizations were split and broadcast. At the beginning of the experiment (September 2010), $20 \%$ of fertilizations were performed, and the others were apportioned after each grazing cycle.

The sward was managed under intermittent stocking with variable stocking rate and grazed by crossbred dairy cows (Holstein-Gyr, Holstein-Jersey and Jersey-Gyr) with an average live weight of 438 $\mathrm{kg}$. The animals were placed on the sward when it had approximately $90 \mathrm{~cm}$ (95\% light interception - measured with the Accupar 80 equipment) and removed when the residue was approximately $40 \mathrm{~cm}$ from soil level. The equivalent height was monitored (three times weekly) at 15 random points in the paddock, using a graduated ruler $(100 \mathrm{~cm})$.

The cumulative stocking rate for the season was calculated, taking the grazing cycles into account and according to the herbage mass production in each treatment. Mean values for herbage mass 
production, according to the treatments, can be observed in Figure 2. The cumulative stocking rate for the season was calculated to express the impact the number of animals can have on the soil and consequently on the root system (Figure 3).

Figure 2. Total herbage mass production of Mombaça grass $\left(\mathrm{t} \mathrm{ha}^{-1}\right)$ as a function of nitrogen fertilization $(\mathrm{kg}$ $\mathrm{ha}^{-1}$ year).

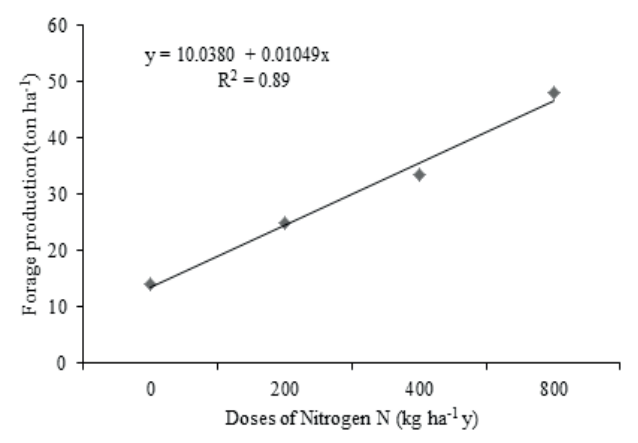

Source: Mari (2013).

Figure 3. Cumulative stocking rate in Mombaça grass pasture as a function of nitrogen fertilization $\left(\mathrm{kg} \mathrm{ha}^{-1}\right.$ year) (A) and season of the year (B).
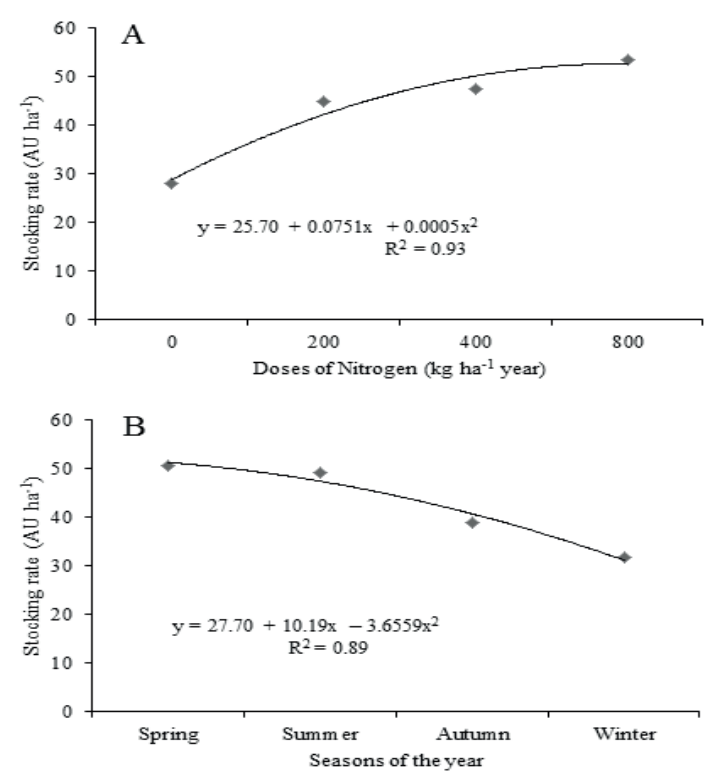

The roots were evaluated every 90 days (one sample per season of the year) using a steel cylinder tube with a volume of $0.3927 \mathrm{~m}^{3}(50-\mathrm{cm}$ long $\times 10$ - $\mathrm{cm}$ wide). Samples of root biomass of the stratified grass were collected at depths of 0-10, 10-20 and $20-40 \mathrm{~cm}$, in the respective treatments. Roots were washed in running water using a 2-mm mesh sieve. Immediately after being washed, they were stored in plastic bottles with $30 \%$ alcohol solution for further analysis.

From each sample, a 1-g aliquot was taken to determine the density $\left(\mathrm{mm} / \mathrm{cm}^{3}\right)$, the area $\left(\mathrm{mm}^{2}\right)$, the diameter $(\mathrm{mm})$ and the length $(\mathrm{mm})$ of the roots using a DELTA T SCAN set with root image analysis software. The remainder of the root mass, previously weighed to determine the root biomass, was dried at $55^{\circ} \mathrm{C}$ for $72 \mathrm{~h}$ in a forced-air oven.

The soil resistance to penetration (RP) was measured with a penetrometer in the $0-40 \mathrm{~cm}$ layer. Samples were collected every 90 days, with five measures of RP in each repetition, and the average of these readings was used. At the same time, soil samples were collected with an auger to determine the moisture content at depths of 0-10, 10-20, 20-30 and $30-40 \mathrm{~cm}$. These samples were oven-dried at $105^{\circ} \mathrm{C}$ for $24 \mathrm{~h}$ to obtain the moisture content, using the ratio between water mass and soil solid mass.

Grouped data were checked for normal distribution, and variance analysis was performed in a completely randomized block with a factorial arrangement with measures repeated over time. Some significant parameters had their means compared by Tukey's test and some were subjected to simple regression, both at 5\% probability, analyzed statistically by $\mathrm{R}$ software (DEVELOPMENT CORE TEAM, 2011).

\section{Results and Discussion}

The root traits (area, diameter, length and density) presented no effects caused by either the nitrogen $(\mathrm{N})$ levels or the evaluated seasons $(\mathrm{P}>0.05)$. These data are agree with Soares-Filho et al. (2013), who also did not observe an effect of $\mathrm{N}$ fertilization on root system when evaluating $P$. 
maximum cv. Tanzânia under grazing fertilized with different $\mathrm{N}$ levels. In this experiment, this effect was not detected in any root trait, since the pasture was in good regrowth vigor, showed no signs of degradation, and presented good soil fertility, water availability, and proper management, which may have caused the lack of responses of roots traits to $\mathrm{N}$ addition.

In addition, the proper amount of dry matter after grazing (40-cm residue) rendered a remnant leaf area, which ensured good regrowth without compromising the root system. Corsi et al. (2001) observed reduction in root growth immediately after grazing, with the highest grazing intensity leading to a lower growth rate and a longer period to resume root growth; thus, the root mass was directly proportional to the remnant leaf area.

Root area, diameter and length were influenced by sampling depth (Table 1), with the highest values found for all traits at $0-10 \mathrm{~cm}$ depth. For all the geometric characteristics, there was an interaction among treatments and collection depth $\times$ seasons, as can be seen in the equations given in Table 2 .
All the characteristics had their values reduced in the dry period in comparison with the rainy season and, also, as soil depth increased. The root biomass was greater in the $0-10 \mathrm{~cm}$ layer, with $91.4 \%$ of the total biomass, while the 10-20 and 20-40 cm depths showed 6.8 and $1.7 \%$ of the biomass, respectively (Table 1). The higher concentration of roots in the top layer is explained by the fasciculate type of root system, which does not reach great depths and generally shows higher concentration in the soil surface layer. Also, these responses are a result of the increased carbon allocation of the root system for this region because of the better nutritional conditions and water availability in this soil layer. Besides, fertilization and liming were performed by broadcasting without incorporation into the soil, which may have increased the concentration of nutrients in this stratum $(0-10 \mathrm{~cm})$. Sarmento et al. (2008) concluded that $60 \%$ of the P. maximum cv. IPR-86 Milênio root system was concentrated in the 0-10 cm layer, while for cv. Tanzânia, SoaresFilho et al. (2013) found about $80 \%$ of the root system in the $0-10 \mathrm{~cm}$ layer for different $\mathrm{N}$ levels tested.

Table 1. Root area, diameter and length and biomass of Mombaça grass as a function of soil depth (cm).

\begin{tabular}{ccccc}
\hline Depth & Area $\left(\mathrm{mm}^{2}\right)$ & Diameter $(\mathrm{mm})$ & Length $(\mathrm{mm})$ & Biomass $\left(\mathrm{kg} \mathrm{m}^{-3}\right)$ \\
\hline $0-10$ & $2953.15 \pm 1148.62 \mathrm{~A}$ & $0.45 \pm 0.15 \mathrm{~A}$ & $7440.69 \pm 1988.86 \mathrm{~A}$ & $4.27 \pm 2.45 \mathrm{~A}$ \\
$10-20$ & $2336.78 \pm 900.87 \mathrm{~B}$ & $0.35 \pm 0.07 \mathrm{~B}$ & $5951.72 \pm 1567.02 \mathrm{~B}$ & $0.32 \pm 0.90 \mathrm{~B}$ \\
$20-40$ & $2142.61 \pm 917.65 \mathrm{~B}$ & $0.31 \pm 0.10 \mathrm{~B}$ & $6039.24 \pm 1503.98 \mathrm{~B}$ & $0.08 \pm 0.98 \mathrm{~B}$ \\
\hline
\end{tabular}

*Different letters in the column differ by Tukey’s test at $5 \%$ probability $(\mathrm{P}<0.05)$.

Table 2. Regression equations and coefficients of determination for root traits of Mombaça grass as a function of season and soil depth $(\mathrm{cm})$.

\begin{tabular}{ccc}
\hline & Equation & $\mathrm{R}^{2}$ \\
\hline Area & $\mathrm{y}=4787.6690-82.6650 \mathrm{x}_{1}-694.9740 \mathrm{x}_{2}+23.2480 \mathrm{x}_{1} \mathrm{x}_{2}$ & 0.81 \\
Diameter & $\mathrm{y}=0.6273-0.0111 \mathrm{x}_{1}-0.0612 \mathrm{x}_{2}+0.0027 \mathrm{x}_{1} \mathrm{x}_{2}$ & 0.75 \\
Length & $\mathrm{y}=12894.2610-388.0030 \mathrm{x}_{1}+5.1090 \mathrm{x}^{2}{ }_{1}-1177.105 \mathrm{x}_{2}+34.3330 \mathrm{x}_{1} \mathrm{x}_{2}$ & 0.76 \\
Density & $\mathrm{y}=8.5096-0.0293 \mathrm{x}_{1}-0.0003 \mathrm{x}^{2}+0.1484 \mathrm{x}_{2}-0.02120 \mathrm{x}_{1} \mathrm{x}_{2}$ & 0.52 \\
\hline
\end{tabular}

* $\mathrm{x} 1$ equation for soil depth, and $\mathrm{x}_{2}$ related to the seasons, and $\mathrm{x}_{1} \mathrm{x}_{2}$ for the interaction between the two variables. 
These data are in agreement with Singh (1999) who, working with Paspalum dilatatum Schum, Pennisetum glaucum L., Pennisetum purpureum Schum. and Brachiaria mutica Stapf., obtained 65$86 \%$ of the total biomass of roots at $0-20 \mathrm{~cm}$ depth and $14-35 \%$ at $20-60 \mathrm{~cm}$ depth when there was no application of $\mathrm{N}$. However, with the application of 50 to $150 \mathrm{~kg} \mathrm{ha}^{-1}$ of $\mathrm{N}$ in the soil surface, there was an increase in the proportion of roots in the soil surface layer (82 to $95 \%$ ) as compared with the deeper layer (5 to $18 \%$ ) (SINGH, 1999).

However, the buildup of roots in the more superficial layers of the soil can make the plant vulnerable to water deficits, since in long periods of dry spells it will be more difficult for the sward to absorb water from deep layers (CUNHA et al., 2010). Another problem derived from the shallow root system is the reduced range for the plant to obtain nutrients from the soil, in which case the plant would require a higher concentration of nutrients in a smaller volume of soil (RIBEIRO et al., 2011). In the present study, in an irrigated sward, the highest concentration of roots was found in this layer, suggesting that the plant did not need to elongate its root system in the soil profile to seek nutrients and water. Hence, the management may have influenced this concentration of roots in the soil surface layer, since root growth is affected by the concentration of nutrients in soil, the availability of water, the soil physical factors, and sward management practices (ANGHINONI; MEURER, 1999).

It is noteworthy that although this study did not present an effect of $\mathrm{N}$ fertilization on the geometric characteristics and root biomass, in their review, Cecato et al. (2004) showed numerous studies in which large amounts of $\mathrm{N}$ were applied to the sward and there was a reduction in root growth at the expense of the development of shoot growth. Thus, if fertilizer management is not appropriate, in certain circumstances it may lead to problems of water and nutrient supply to plants, given the reduced ability of their roots to explore the soil.
According to Imhoff et al. (2000), a limit of PR $=2500 \mathrm{kPa}$ was considered as the critical value from which there is mechanical impediment to root growth for Gramineae. The soil PR presented a quadratic effect of the soil depths (Figure 4-A), with the lowest PR in the first $10 \mathrm{~cm}$ of soil, increasing at 10-20 and 20-30 cm depths. The lowest PR at 0-10 $\mathrm{cm}$ is associated with the highest concentration of root biomass in this soil layer, which corroborates the data from Sarmento et al. (2008), who, evaluating the root system of IPR-86 Millennium grass, found a higher concentration of roots in the soil surface layer, which had the lowest PR compared with the deeper layers. The intermediate layers exceeded the critical PR value, which may be due to the particlesize characteristics of this soil (clay and silt) and the naturally increasing PR, or the natural soil compaction at further depths.

Figure 4. Soil penetration resistance $(\mathrm{kPa})$ of Mombaça grass pasture as a function of soil depth $(\mathrm{cm})(\mathrm{A})$ and season of the year (B).
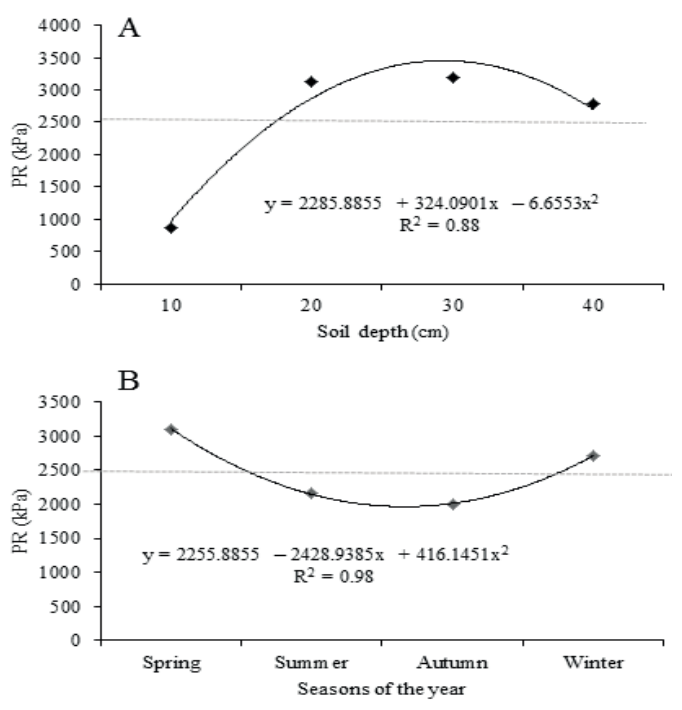

According to Glinski and Lipiec (1990), mechanical restraints on the soil surface resulted in a superficial accumulation of "bluegrass" (Poa pratensis $\mathrm{L}$ ), maize and barley roots, and affected the vertical and horizontal distribution of corn 
roots throughout the soil profile. According to these authors, this accumulation can promote uneven distribution of nutrients and, at the same time, depletion of nutrients in the surface layers. When the mechanical obstacles were located at the base of the plow layer, there was a reduction in the density of corn roots not only in the compressed area, but also throughout the profile, and these changes in root proliferation and growth in the soil profile may limit the uptake of water and nutrients by plants (GLINSKI; LIPIEC, 1990).

There was a quadratic effect for PR in the seasons (Figure 4-B), with a decline from spring to fall and a rise in the winter. This may have occurred because the area was poorly managed in the years prior to the experiment, with high grazing pressures, far beyond its carrying capacity. In this work, we used the stocking density based on herbage availability coupled with appropriate management (day of occupation and rest), based on light interception with plant physiology being respected, thereby benefiting the unpacking of this soil during the following seasons. Also, another factor that may have contributed to the decrease in RP is the fact that the spring, summer and fall seasons were responsible for the highest herbage yield (Figure 2), and thus a greater production of dead material may have occurred, allowing greater soil coverage and moisture conservation. The higher PR in the winter may be explained by the lower water content in the soil in this period (Figure 5-B), since irrigation in the area was not sufficient to fulfill limitations from the dry environment, typical of the season.

Figure 5. Soil water content $\left(\mathrm{kg} \mathrm{kg}^{-1}\right)$ in Mombaça grass pasture as a function of nitrogen fertilization $\left(\mathrm{kg} \mathrm{ha}^{-1}\right.$ year) (A) and season of the year (B).

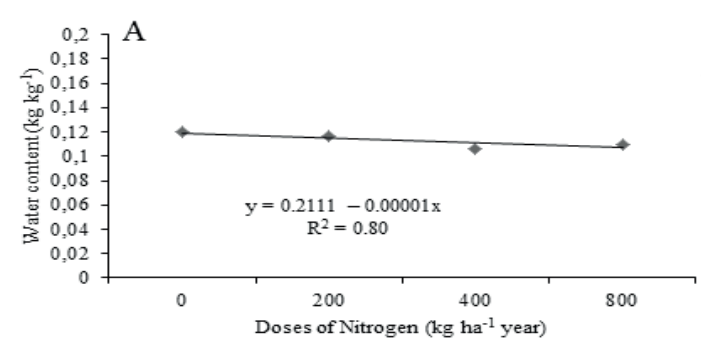

There was a significant interaction effect between $\mathrm{N}$ levels and seasons of the year on PR $(\mathrm{P}<0.05)$; the highest values were found in the treatments with 400 and $800 \mathrm{~kg} \mathrm{~N} \mathrm{ha}^{-1}$ year. These levels provided higher herbage mass production (Figure 2), a larger number of grazing sessions, and consequently the highest cumulative stocking rate in all experimental periods, with a greater concentration in the rainy season (Figure 3). This is the season with the best climatic conditions for the development of herbage, which, associated with irrigation, leads to higher herbage production, increasing the stocking rate in tropical pastures. However, soil compaction caused by animal

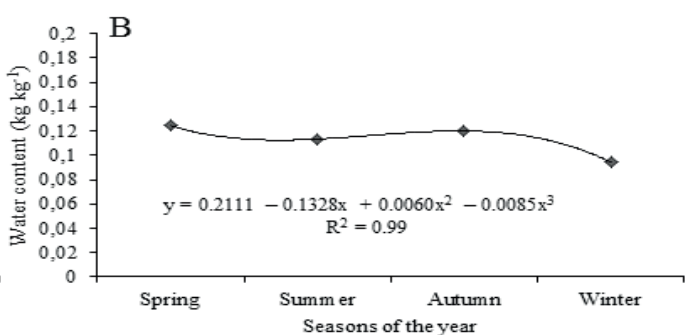

trampling contributes to reduced productivity and longevity of pastures (IMHOFF et al., 2000).

Treatments with 400 and $800 \mathrm{~kg} \mathrm{~N} \mathrm{ha}^{-1}$ resulted in lower moisture in the soil (Figure 5A), because of the higher demand for water needed for plant growth. Yet, regardless of the $\mathrm{N}$ level, the PR was higher in the winter, due to the lower water content in the soil in that season (Figure 5B). The occurrence of periods of water stress reduces water content in the soil and consequently increases $\mathrm{PR}$, resulting in greater mechanical barrier to root growth and consequently to plant growth in general. However, according to Nichols and Clanton (1985), often irrigated pastures on soils with texture tending 
to sandy may not require complete removal of the stocking. Higher density of roots and litter reduce the action of animal trampling that promotes soil compaction (NICHOLS; CLANTON, 1985). Besides, evidence suggests that grasses increase soil porosity (FIDALSKI; TORMENA, 2007). In areas in which grass forages are well managed, it is unlikely that soil compaction occurs, because the source-drain dynamics between roots and leaves during defoliation (RODRIGUES et al., 2007) allows increased soil porosity in the same proportion as cattle trampling reduces this physical property.

\section{Conclusions}

The increase in stocking rate resulting from from the increased levels of nitrogen fertilization in a Mombaça grass pasture does not directly affect the penetration resistance of the soil or its root characteristics.

Increasing nitrogen fertilizer levels in the rainy season enhances the soil penetration resistance.

The largest biomass and length of roots occur in the superficial stratum of the soil due to the lower penetration resistance in this layer.

\section{Acknowledgments}

The authors thank CNPq (Conselho Nacional de Desenvolvimento Cientifico e Tecnológico, Brazil) for the financial support.

\section{References}

ANGHINONI, I.; MEURER, E. J. Eficiência de absorção de nutrientes pelas raízes. In: WORKSHOP SOBRE SISTEMA RADICULAR: METODOLOGIAS E ESTUDO DE CASO, 1., 1999, Aracajú. Anais... Aracajú: EMBRAPA, 1999. p. 57-58.

BERTOL, I.; ALMEIDA, J. A.; ALMEIDA, E. X.; KURTZ, C. Propriedades físicas do solo relacionadas a diferentes níveis de oferta de forragem de capim-elefanteanão cv. Mott. Pesquisa Agropecuária Brasileira, Brasília, v. 35, n. 5, p. 1047-1054, 2000.
CECATO, U.; JOBIM, C. C.; REGO, F. C. A.; LENZI, A. Sistema radicular - componente esquecido das pastagens. In: II SIMPÓSIO SOBRE O MANEJO ESTRATÉGICO DA PASTAGEM, 2., 2004, Viçosa, MG. Anais... Viçosa, MG: UFV, 2004. p. 159-207.

CORSI, M.; MARTHA JÚNIOR, G. B.; PAGOTTO, D. S. Sistema radicular: dinâmica e resposta a regimes de desfolha. In: MATTOS, W. R. S.; FARIA, V. P.; SILVA, S. C.; NUSSIO, L. G.; MOURA, J. C. (Ed.). A produção animal na visão dos brasileiros. Piracicaba: FEALQ, 2001. p. 838-852.

CUNHA, F. F.; RAMOS, M. M.; ALENCAR, C. A. B.; MARTINS, C. E.; COSER, A. C.; OLIVEIRA, R. A. Sistema radicular de seis gramíneas irrigadas em diferentes adubações nitrogenadas e manejos. Acta Scientiriarum Agronomy, Maringá, v. 32, n. 2, p. 351$357,2010$.

DIAS, P. F.; ROCHA, G. P.; ROCHA FILHO, R. R.; LEAL, M. A. A.; ALMEIDA, D. L.; SOUTO, S. M. Produção e valor nutritivo de gramíneas forrageiras tropicais avaliadas no período das águas, sob diferentes doses de nitrogênio. Ciência e Agrotecnologia, Lavras, v. 24, n. 1, p. 260-271, 2000.

EMPRESA BRASILEIRA DE PESQUISA AGROPECUÁRIA - EMBRAPA. Centro Nacional de Pesquisa de Solos. Sistema brasileiro de classificação de solos. 2. ed. Rio de Janeiro: EMBRAPA-SPI, 2009. 412 p.

FIDALSKI, J.; TORMENA, C.A. Homogeneidade da qualidade física do solo nas entrelinhas de um pomar de laranjeira com sistemas de manejo da vegetação permanente. Revista Brasileira de Ciência do Solo, Viçosa, v. 31, n. 4, p. 637-645, 2007.

GLINSKI, J.; LIPIEC, J. Soil physical conditions and plant roots. Boca Raton: CRC Press, 1990. 250 p.

IIJIMA, M.; KONO, Y. Interspecific differences of the root system structures of four cereal species as affected by soil compaction. Japanese Journal of Crop Science, Tokyo, v. 60, n. 1, p. 130-138, 1991.

IMHOFF, S.; SILVA, A. P. da; TORMENA, C. A. Aplicações da curva de resistência no controle da qualidade física de um solo sob pastagem. Pesquisa Agropecuária Brasileira, Brasília, v. 35, n. 7, p. 14931500, 2000.

LOPES, R. S.; FONSECA, D. M.; OLIVEIRA, R. A.; NASCIMENTO JUNIOR, D.; ANDRADRE, A. C.; STOCK, A. L.; MARTINS, C. E. Disponibilidade de matéria seca em pastagens de capim-elefante irrigadas. Ciência e Agrotecnologia, Lavras, v. 27, n. 1, p. 13881394, 2003. 
MARTHA JUNIOR, G. B.; CORSI, M.; TRIVELIN, P. C. O.; VILELA, L.; PINTO, T. L. F.; TEIXEIRA, G. M.; MANZONI, C. S.; BARIONI, L. G. Perda de amônia por volatilização em pastagem de Capim-Tanzânia adubada com ureia no verão. Revista Brasileira de Zootecnia, Viçosa, MG, v. 33, n. 6, p. 2240-2247, 2004.

MARI, G. C. Características morfológicas e produtivas e a composição química do capim-Mombaça irrigado e fertilizado ou não com nitrogênio, sob pastejo. 2013. Dissertação (Mestrado em Zootecnia) - Universidade Estadual de Maringá, Maringá.

MEROTTO, A.; MUNDSTOCK, C. M. Wheat root growth as affected by soil strength. Revista Brasileira de Ciência do Solo, Viçosa, MG, v. 23, n. 2, p. 197-202, 1999.

NICHOLS, J. T.; CLANTON, D. C. Irrigated pastures. In: HEATH, M. E.; BARNES, R. F.; METCALF, D. S. (Ed.). Forages: the science of grassland agriculture. Iowa: PRESS, 1985. p. 507-516.

RIBEIRO, O. L.; CECATO, U.; RODRIGUES, A. M.; FAVERI, J. C.; JOBIM, C. C.; LUGÃO, S. M. B. Biomassa radicular e reservas orgânicas em Coastcross consorciada ou não com "Arachis pintoi", com e sem nitrogênio, sob pastejo. Revista Brasileira de Saúde e Produção Animal, Salvador, v. 12, n. 2, p. 318-328, 2011.

RODRIGUES, R. C.; MOURÃO, G. B.; VALINOTE, A. C.; HERLING, V. R. Reservas orgânicas, relação parte aérea-raiz e c-n e eliminação do meristema apical no capim-xaraés sob doses de nitrogênio e potássio. Ciência Animal Brasileira, Goiânia, v. 8, n. 3, p. 505514, 2007.
SARMENTO, P.; RODRIGUES, L. R. A.; LUGÃO, S. M. B.; CRUZ, M. C. P.; CAMPOS, F. P.; FERREIRA, M. E.; OLIVEIRA, R. F. Sistema radicular do Panicum maximum Jacq. Cv. IPR-86 Milênio adubado com nitrogênio e submetido a lotação rotacionada. Revista Brasileira de Zootecnia, Viçosa, MG, v. 37, n. 1, p. $27-$ 34, 2008.

SINGH, K. A. Effect of nitrogen levels on yield, root biomass distribution, nitrogen recovery by forage grasses and changes in soil properties of acid Inceptisol. Indian Journal of Agricultural Sciences, New Delhi, v. 69, n. 8, p. 551-554, 1999.

SOARES-FILHO, C. V.; CECATO, U.; RIBEIRO, O. L.; ROMA, C. F. C.; JOBIM, C. C.; BELONI, T.; PERRI, S. H. V. Root system and root and stem base organic reserves of pasture Tanzania grass fertilizer with nitrogen under grazing. Semina: Ciências Agrárias, Londrina v. 34, n. 5, p. 2415-2426, 2013.

SORIA, L. G. T.; COELHO, R. D.; HERLING, V. R.; PINHEIRO V. Resposta do capim Tanzânia a aplicação do nitrogênio e de lâminas de irrigação. I: Produção de forragem. Revista Brasileira de Engenharia Agrícola e Ambiental, Campina Grande, v. 7, n. 3, p. 430-436, 2003.

VALENTIM, J. F.; CARNEIRO, J. C.; SALES, M. F. L. Amendoim forrageiro $\mathrm{cv}$. Belmonte: leguminosa para a diversificação das pastagens e conservação do solo no Acre. Rio Branco: Embrapa-CPAF Acre, 2001. 18 p. (Circular técnica, 43).

WERNER, J. C.; PAULINO, V. T.; CANTARELLA, H.; ANDRADE, N. O.; QUAGGIO, J. A. Forrageiras. In: RAIJ, B. van; CANTARELLA, H.; QUAGGIO, J. A.; FURLANI, A. M. C. (Ed.). Recomendações de adubação e calagem para o Estado de São Paulo. Campinas: Instituto Agronômico, 1996. p. 263-273. (IAC. Boletim técnico, 100). 
